\title{
Heart transplantation and its long-term outcomes
}

\author{
Kaan İnce', (1) Oytun Erbaş² (1) \\ ${ }^{1}$ Demiroğlu Bilim University School of Medicine, Istanbul, Turkey \\ ${ }^{2}$ Department of Physiology, Demiroğlu Bilim University School of Medicine, Istanbul, Turkey
}

\begin{abstract}
Heart transplantation increases quality of life and life expectancy in patients with end stage heart failure. Patients diagnosed with severe heart failure via cardiopulmonary function tests are candidates for heart transplantation. Immunosuppressive treatment administered after transplantation is a three-drug treatment method used to weaken the recipient's immune system in order to prevent rejection of the transplanted organ. While early-term complications of heart transplant include primary graft incompatibility, right ventricular failure, and infections, malignancies and cardiac allograft vasculopathy (CAV) are among late-term complications. The past decade has revealed $50 \%$ increased incidence of post-transplant CAV which is difficult to diagnose and treat to this day.

Keywords: Cardiac allograft vasculopathy, heart transplant complications, heart transplant, immunosuppressive treatment, transplantation rejection.
\end{abstract}

\section{HEART TRANSPLANTATION}

The first human-to-human heart transplantation was perceived as a speculation for a long time until it was performed in 1967 by Christiaan Barnard and was later widely accepted in the medical community, given the positive outcomes of longterm survival and quality of life in patients. ${ }^{[1]}$

Heart transplantation is the gold standard treatment in patients with end stage heart failure that is unresponsive to treatment, ${ }^{[2]}$ and is the third most commonly performed organ transplantation procedure in organ transplantation centers. ${ }^{[3,4]}$

Heart transplantation may be considered in patients with symptoms of heart failure at rest or during mild physical activity despite undergoing all treatments, frequent hospitalizations, and in those with unsatisfactory response to medical and surgical treatments. However, these factors alone are insufficient. In the cardiopulmonary function test, which plays a critical role in the decisionmaking process for transplantation, the patient's respiratory, circulatory, and musculoskeletal systems are all tested and evaluated in order to estimate the recipient's status and potential complications following transplantation.

During the cardiopulmonary test, the patient is given an exercise in the form of pedal cycling, yielding data on the amount of oxygen and carbon dioxide volumes, general respiratory adequacy and muscle metabolism during exercise stress. ${ }^{[5,6]}$ In particular, the maximum oxygen consumption $\left(\mathrm{VO}_{2}\right)$ is higher and ventilation/ carbon dioxide production slope is lower in heart failure patients compared to healthy people, showing strong resemblance to the later stages of heart failure. ${ }^{[6,7]}$

Some of the medical requirements and contraindicatory factors of heart transplantation are provided in Table 1. In addition to the listed factors, presence of other diseases accompanying heart failure such as infections or neoplasms should be treated to reevaluate transplantation. 
Table 1. Some medical requirements for heart transplantation and factors that prevent transplantation

\begin{tabular}{ll}
\hline Indication & Contraindication \\
\hline $\mathrm{VE} / \mathrm{VCO}_{2}>35$ & Severe psychiatric disease, incompliance to treatment \\
$\mathrm{VO}_{2} \leq 12 \mathrm{~mL} / \mathrm{kg} / \mathrm{min}$ (with beta blocker use) & Severe peripheral vascular disease, substance abuse \\
$\mathrm{VO}_{2} \leq 14 \mathrm{~mL} / \mathrm{kg} / \mathrm{min}$ (without beta blocker use) & Severe renal failure \\
Persistent functional class III or IV & Severe cerebrovascular disease \\
$\begin{array}{l}\text { Ischemic disease with angina unresponsive to treatment that cannot } \\
\text { be treated with revascularization }\end{array}$ & Severe pulmonary heart disease \\
VAD or unresponsive HF during inotropic use & Pulmonary hypertension (PVR $>5$ Wood units) \\
Persistent or unresponsive ventricular arrythmia & Incompatibility between donor and recipient in ABO cross-match test \\
\hline
\end{tabular}

$\mathrm{VO}_{2}$ : Maximum oxygen consumption volume; $\mathrm{VE} / \mathrm{VCO}_{2}$ : Ratio of respiration volume to carbon dioxide volume; VAD: Ventricular assist device; HF: Heart failure; PVR: Pulmonary vascular resistance; Functional class: WHO rated classes of pulmonary hypertension.

High-risk factors such as pre- and posttransplantation peripheral vascular disease (PVD), ${ }^{[8]}$ pre-transplantation renal failure (PRF), ${ }^{[9,10]}$ and cerebrovascular accidents $(\mathrm{CVAs})^{[11]}$ play a critical role in the decision-making process of transplantation. Furthermore, corticosteroid drugs included in post-transplantation immunosuppressant treatment increases levels of blood sugar in diabetes patients, making treatment difficult. However, the main factor that prevents transplantation is presence of any end organ failure. ${ }^{[12]}$

\section{Early-term complications and immunosuppressive treatment}

Currently, the one-year survival rate following heart transplantation is around $90 \%,{ }^{[13]}$ however elderly patient age due to increased life expectancy has increased tendency to poor outcomes such as primary tissue mismatch or antigen-related mismatch. ${ }^{[13-15]}$

Early term complications include primary tissue mismatch, which accounts for 36\% of deaths within the first 30 days, ${ }^{[16]}$ right ventricular insufficiency ${ }^{[17]}$ which causes pulmonary hypertension and is responsible for $50 \%$ of early complications, and infections induced by opportunist pathogens especially due to immunosuppressive therapy ${ }^{[5]}$ which occupy the largest majority.

Endomyocardial biopsies are performed to detect the early stages of organ rejection. These biopsies can identify three types of organ rejection: hyperacute, cellular, or humoral (or antibodymediated) rejection. ${ }^{[18]}$ Hyperacute humoral rejection caused by previously formed antibodies against the donor (HLA or ABO) is a rare but very severe form of organ rejection. Acute cellular rejection, characterized by inflammatory cells found in the myocardium, is the most common form of organ rejection and its severe forms require additional immunosuppressive treatment. ${ }^{[19]}$ Acute humoral rejection or antibody-mediated rejections generally manifest as anti-HLA antibodies in

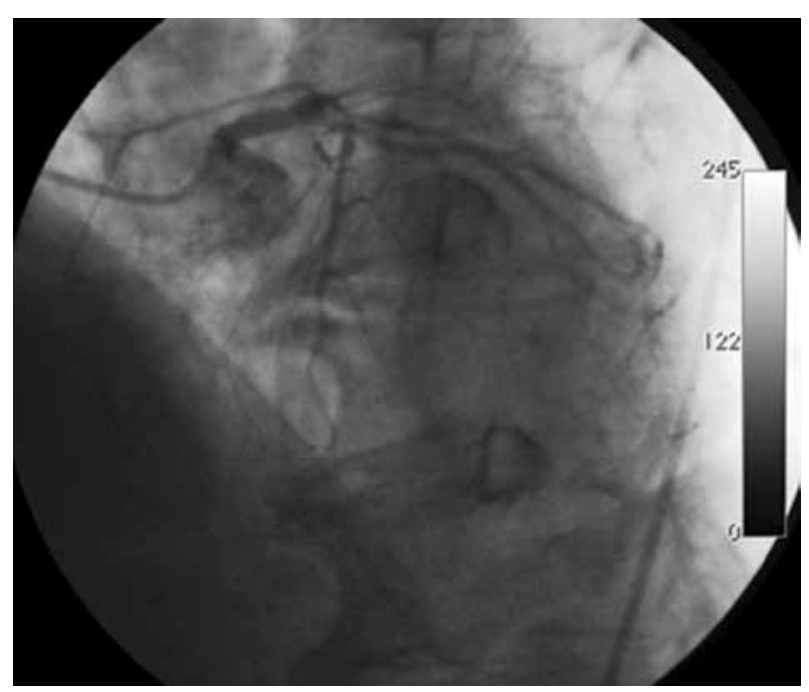

Figure 1. Coronary angiography of a cardiac allograft vasculopathy patient who underwent heart transplantation six years ago. Diffuse narrowing of the left anterior descending artery of the heart and disappearance of the distal end of the left circumflex artery is shown. ${ }^{[35]}$ Cardiac allograft vasculopathy disrupts the vasculature of the transplanted heart with a stiffening effect. Prolonged smooth muscle cell proliferation, inflammatory cell and fat accumulation cause thickening of the circumferential vessels of the heart. ${ }^{[34]}$ 
the transplanted organ or tissue's vascular endothelium. ${ }^{[20]}$ However, in some cases, antiHLA antibodies in conjunction with non-HLA antibodies can cause acute humoral rejection. One example of this is angiotensin II hormone receptor antibody. The angiotensin II hormone, responsible for maintaining the body's overall fluid content, functions with a $G$ protein-bound type 1 angiotensin receptor (AT1R) ${ }^{[21]}$ on the surface of vascular endothelial cells in the body. This receptor's antibody is a non-HLA AT1R antibody which significantly increases the risk of acute antibody-mediated rejection and acute cellular rejection if it has elevated levels together with the HLA type antibody, HLA-donor-specific antibodies (DSA). ${ }^{[22,23]}$

Immunosuppressive treatment is a threedrug treatment method used to weaken the recipient's immune system after transplantation to prevent organ rejection. The drugs used in immunosuppression include calcineurin inhibitor (CNI) (cyclosporin or tacrolimus), antimetabolite agent (mycophenolate mofetil [MMF] or azathioprine), and corticosteroid to be used for a period of one year after transplantation in gradually decreasing doses. ${ }^{[24]}$ Antiproliferative agents (PSIs) and mTOR inhibitors (sirolimus and everolimus) are novel drugs used in immunosuppressive treatment compared to conventional drugs. ${ }^{[25]}$ mTOR inhibitors (sirolimus and everolimus) has been shown to decrease cardiac allograft vasculopathy (CAV) progression and probability. ${ }^{[26,27]}$ and risk of neoplasm and viral infections as late term complications. ${ }^{[28,29]}$

\section{Cardiac allograft vasculopathy and other late-term complications}

Malignancies and CAV are the most common late-term complications. Post-transplantation malignancies are more common in heart transplant compared to other organ transplants. This is because more prophylactic drugs are used in immunosuppression. ${ }^{[30,31]}$ Skin cancer accounts for about $50 \%$ of all post-transplant malignancies and is the most common type. ${ }^{[32]}$ Lymphoproliferative disorders, Kaposi sarcoma, and tumors are other significant post-transplant malignancies. ${ }^{[33]}$

Cardiac allograft vasculopathy is the largest cause of late-term complications after heart transplantation. It has $8 \%$ incidence rate in the first year after transplant, $30 \%$ in the first five years, and $50 \%$ in the first 10 years. ${ }^{[16]}$

Cardiac allograft vasculopathy is a slow progressing disease that is initially asymptomatic or manifests symptoms nonspecific to CAV and therefore, difficult to diagnose. When symptoms initially occur, the disease has already progressed to later stages and irreversible myocardial damage may lead to sudden death. Tissue disorders seen in routine echocardiographic follow-up or annual angiography may indicate CAV. However, since angiography is not sensitive to some changes in vascular structure caused by the disease, it may be inadequate for identifying CAV. Therefore, intravascular ultrasonography (IVUS) used to see the inside of the vessel is accepted as the gold standard for CAV diagnosis. ${ }^{[3,35]}$

\section{Heart transplantation cases}

A total of 350 routing coronary angiographies were conducted on 105 patients over an 18 -month period. Tissue disorders that may be indicative of CAV were identified in 43 or the patients. Of these 43 patients, 15 had serious damage due to over $50 \%$ narrowing of the coronary vessel. Age of these patients ranged between 27 and 68 years and all of them were male. Nine of those patients underwent PTCA (percutaneous transluminal coronary angioplasty). Cyclosporine and prednisone were administered to all and azathioprine was administered to seven of the patients. Within the first month after the initial PTCA, ischemic disorders were detected in all nine patients with dobutamine stress echocardiography. In addition, three of the patients developed myocardial infarction. All patients were administered daily aspirin with doses ranging from $100-250 \mathrm{mg}$. Over the next four years, a total of 23 surgical operations (PTCA and stent implantation) were performed on 37 critical stenoses. All additional interventions were successful with no bleeding complications. Over the next 6-47 months, angiographic follow-ups and additional procedures including PTCA and stent implantations were performed. As a result, no cardiac death occurred between 7 and 51 months after the first procedure. One patient died 21 months after the first PTCA procedure due to myeloma. No new myocardial infarction cases occurred. Two patients with dyspnea were treated with balloon angioplasty and symptoms 
resolved. A 60-year-old patient was offered a recommendation for retransplantation. ${ }^{[36]}$

\section{Declaration of conflicting interests}

The authors declared no conflicts of interest with respect to the authorship and/or publication of this article.

\section{Funding}

The authors received no financial support for the research and/or authorship of this article.

\section{REFERENCES}

1. Stolf NAG. History of Heart Transplantation: a Hard and Glorious Journey. Braz J Cardiovasc Surg 2017;32:423-7.

2. Macdonald P. Heart transplantation: who should be considered and when? Intern Med J 2008;38:911-7.

3. Sampaio MS, Cho YW, Qazi Y, Bunnapradist S, Hutchinson IV, Shah T. Posttransplant malignancies in solid organ adult recipients: an analysis of the U.S. National Transplant Database. Transplantation 2012;94:990-8.

4. Engels EA, Pfeiffer RM, Fraumeni JF Jr, Kasiske BL, Israni AK, Snyder JJ, et al. Spectrum of cancer risk among US solid organ transplant recipients. JAMA 2011;306:1891-901.

5. Mangini S, Alves BR, Silvestre OM, Pires PV, Pires LJ, Curiati MN, et al. Heart transplantation: review. Einstein (Sao Paulo) 2015;13:310-8.

6. Albouaini K, Egred M, Alahmar A, Wright DJ. Cardiopulmonary exercise testing and its application. Postgrad Med J 2007;83:675-82.

7. Myers J, Arena R, Dewey F, Bensimhon D, Abella J, Hsu L, et al. A cardiopulmonary exercise testing score for predicting outcomes in patients with heart failure. Am Heart J 2008;156:1177-83.

8. Centers for Disease Control and Prevention (CDC). Incidence of end-stage renal disease among persons with diabetes--United States, 1990-2002. MMWR Morb Mortal Wkly Rep 2005;54:1097-100.

9. Russo MJ, Chen JM, Hong KN, Stewart AS, Ascheim $\mathrm{DD}$, Argenziano $\mathrm{M}$, et al. Survival after heart transplantation is not diminished among recipients with uncomplicated diabetes mellitus: an analysis of the United Network of Organ Sharing database. Circulation 2006;114:2280-7.

10. Brancati FL, Whelton PK, Randall BL, Neaton JD, Stamler J, Klag MJ. Risk of end-stage renal disease in diabetes mellitus: a prospective cohort study of men screened for MRFIT. Multiple Risk Factor Intervention Trial. JAMA 1997;278:2069-74.

11. Almdal T, Scharling $H$, Jensen JS, Vestergaard $H$. The independent effect of type 2 diabetes mellitus on ischemic heart disease, stroke, and death: a population-based study of 13,000 men and women with 20 years of follow-up. Arch Intern Med
2004;164:1422-6.

12. Moss SE, Klein R, Klein BE. Long-term incidence of lower-extremity amputations in a diabetic population. Arch Fam Med 1996;5:391-8.

13. Yusen RD, Edwards LB, Dipchand AI, Goldfarb SB, Kucheryavaya AY, Levvey BJ, et al. The Registry of the International Society for Heart and Lung Transplantation: Thirty-third Adult Lung and HeartLung Transplant Report-2016; Focus Theme: Primary Diagnostic Indications for Transplant. J Heart Lung Transplant 2016;35:1170-84.

14. Colvin M, Smith JM, Skeans MA, Edwards LB, Uccellini K, Snyder JJ, et al. OPTN/SRTR 2015 Annual Data Report: Heart. Am J Transplant 2017;17:286-356.

15. Nwakanma LU, Williams JA, Weiss ES, Russell $\mathrm{SD}$, Baumgartner WA, Conte JV. Influence of pretransplant panel-reactive antibody on outcomes in 8,160 heart transplant recipients in recent era. Ann Thorac Surg 2007;84:1556-62.

16. Lund LH, Edwards LB, Kucheryavaya AY, Dipchand $\mathrm{AI}$, Benden C, Christie JD, et al. The Registry of the International Society for Heart and Lung Transplantation: Thirtieth Official Adult Heart Transplant Report--2013; focus theme: age. J Heart Lung Transplant 2013;32:951-64.

17. Stobierska-Dzierzek B, Awad H, Michler RE. The evolving management of acute right-sided heart failure in cardiac transplant recipients. J Am Coll Cardiol 2001;38:923-31.

18. Bacal F, Neto JD, Fiorelli AI, Mejia J, MarcondesBraga FG, Mangini S, et al. [II Brazilian Guidelines for Cardiac Transplantation]. Arq Bras Cardiol 2010;94:e16-76.

19. Stewart S, Winters GL, Fishbein MC, Tazelaar HD, Kobashigawa $\mathrm{J}$, Abrams $\mathrm{J}$, et al. Revision of the 1990 working formulation for the standardization of nomenclature in the diagnosis of heart rejection. $\mathrm{J}$ Heart Lung Transplant 2005;24:1710-20.

20. Wu GW, Kobashigawa JA, Fishbein MC, Patel JK, Kittleson MM, Reed EF, et al. Asymptomatic antibodymediated rejection after heart transplantation predicts poor outcomes. J Heart Lung Transplant 2009;28:417-22.

21. Sevá Pessôa B, van der Lubbe N, Verdonk K, Roks AJ, Hoorn EJ, Danser AH. Key developments in renin-angiotensin-aldosterone system inhibition. Nat Rev Nephrol 2013;9:26-36.

22. Reinsmoen NL, Lai CH, Mirocha J, Cao K, Ong $G$, Naim $M$, et al. Increased negative impact of donor HLA-specific together with non-HLA-specific antibodies on graft outcome. Transplantation 2014;97:595-601.

23. Zhang Q, Reed EF. The importance of non-HLA antibodies in transplantation. Nat Rev Nephrol 2016;12:484-95.

24. Kittleson MM, Kobashigawa JA. Cardiac Transplantation: Current Outcomes and Contemporary 
Controversies. JACC Heart Fail 2017;5:857-68.

25. Gharbi C, Gueutin V, Izzedine H. Oedema, solid organ transplantation and mammalian target of rapamycin inhibitor/proliferation signal inhibitors (mTOR-I/PSIs). Clin Kidney J 2014;7:115-20.

26. Mancini D, Pinney S, Burkhoff D, LaManca J, Itescu $\mathrm{S}$, Burke $\mathrm{E}$, et al. Use of rapamycin slows progression of cardiac transplantation vasculopathy. Circulation 2003;108:48-53.

27. Eisen HJ, Kobashigawa J, Starling RC, Pauly DF, Kfoury A, Ross $\mathrm{H}$, et al. Everolimus versus mycophenolate mofetil in heart transplantation: a randomized, multicenter trial. Am J Transplant 2013;13:1203-16.

28. Chapman JR, Valantine H, Albanell J, Arns WA, Campistol JM, Eisen $\mathrm{H}$, et al. Proliferation signal inhibitors in transplantation: questions at the cutting edge of everolimus therapy. Transplant Proc 2007;39:2937-50.

29. Baraldo M, Gregoraci G, Livi U. Steroid-free and steroid withdrawal protocols in heart transplantation: the review of literature. Transpl Int 2014;27:515-29.

30. Rinaldi M, Pellegrini C, D'Armini AM, Aiello M, Negri M, Arbustini E, et al. Neoplastic disease after heart transplantation: single center experience. Eur J Cardiothorac Surg 2001;19:696-701.

31. Goldstein DJ, Williams DL, Oz MC, Weinberg AD, Rose EA, Michler RE. De novo solid malignancies after cardiac transplantation. Ann Thorac Surg 1995;60:1783-9.

32. Penn I. Tumors after renal and cardiac transplantation. Hematol Oncol Clin North Am 1993;7:431-45.

33. Lateef N, Abdul Basit K, Abbasi N, Kazmi SM, Ansari AB, Shah M. Malignancies After Heart Transplant. Exp Clin Transplant 2016;14:12-6.

34. Chih S, Chong AY, Mielniczuk LM, Bhatt DL, Beanlands RS. Allograft Vasculopathy: The Achilles' Heel of Heart Transplantation. J Am Coll Cardiol 2016;68:80-91.

35. Skoric B, Cikes M, Ljubas Macek J, Baricevic Z, Skorak I, Gasparovic H, et al. Cardiac allograft vasculopathy: diagnosis, therapy, and prognosis. Croat Med J 2014;55:562-76.

36. Redonnet $\mathrm{M}$, Tron $\mathrm{C}$, Koning $\mathrm{R}$, Bouchart $\mathrm{F}$, Cribier A, Soyer R, et al. Coronary angioplasty and stenting in cardiac allograft vasculopathy following heart transplantation. Transplant Proc 2000;32:463-5. 